Article

\title{
Long-Term Dynamic of Land Reclamation and Its Impact on Coastal Flooding: A Case Study in Xiamen, China
}

\author{
Lilai $\mathrm{Xu}^{1,2}$, Shengping Ding ${ }^{3}$, Vilas Nitivattananon ${ }^{4}$ and Jianxiong Tang ${ }^{5, *}$ \\ 1 Institute for Disaster Management and Reconstruction, Sichuan University, Chengdu 610065, China; \\ lilaixu@scu.edu.cn \\ 2 Research Center for Integrated Disaster Risk Reduction and Emergency Management, Sichuan University, \\ Chengdu 610065, China \\ 3 Key Lab of Urban Environment and Health, Institute of Urban Environment, Chinese Academy of Sciences, \\ Xiamen 361021, China; spding@iue.ac.cn \\ 4 Asian Institute of Technology, Pathum Thani 12120, Thailand; vilasn@ait.asia \\ 5 Xiamen Municipal Natural Resources and Planning Bureau, Xiamen 361012, China \\ * Correspondence: jxtang@iue.ac.cn
}

check for

updates

Citation: Xu, L.; Ding, S.;

Nitivattananon, V.; Tang, J.

Long-Term Dynamic of Land

Reclamation and Its Impact on

Coastal Flooding: A Case Study in

Xiamen, China. Land 2021, 10, 866.

https://doi.org/10.3390/

land10080866

Academic Editors: Quazi K. Hassan and Luís Carlos Loures

Received: 19 July 2021

Accepted: 16 August 2021

Published: 18 August 2021

Publisher's Note: MDPI stays neutral with regard to jurisdictional claims in published maps and institutional affiliations.

Copyright: (c) 2021 by the authors. Licensee MDPI, Basel, Switzerland. This article is an open access article distributed under the terms and conditions of the Creative Commons Attribution (CC BY) license (https:/ / creativecommons.org/licenses/by/ $4.0 /)$.

\begin{abstract}
While land reclaimed from the sea meets the land demand for coastal development, it simultaneously causes socio-economic systems to be prone to coastal flooding induced by storm surges and sea-level rise. Current studies have seldom linked reclamation with coastal flood impact assessment, hindering the provision of accurate information to support coastal flood risk management and adaptation. This study, using Xiamen, China as a case study, incorporates the spatiotemporal dynamics of reclamation into a coastal flood impact model, in order to investigate the long-term influence of reclamation activities on coastal flood inundation and the consequent exposure of the population to coastal flooding. We find that rapid population growth, continual economic development and urbanization drive a substantial logarithmic increase in coastal reclamation. Historical and future expansions of seaward land reclamation are found to cause dramatic surges in the expected annual inundation (EAI) and the expected annual population (EAP) exposed to coastal flooding. In Xiamen, EAI is estimated to increase by 440.2\% from 1947 to 2035, owing to continuing land reclamation. Consequently, the population living in the flooded area has also increased sharply: the EAP of total population is estimated to rise from $0.8 \%$ in 1947 to $4.7 \%$ in 2035, where reclamation contributes over $80 \%$ of this increase. Moreover, a future $10 \mathrm{~cm}$ sea-level rise in 2035 will lead to extra $5.73 \%$ and $8.15 \%$ increases in EAI and EAP, respectively, and is expected to cause massive permanent submersion in the new reclamation zone. Our findings emphasize an integration of hard structures and nature-based solutions for building resilient coasts.
\end{abstract}

Keywords: reclamation; coastal flooding; population exposure; sea-level rise; nature-based solutions

\section{Introduction}

Rapid increases in coastal urbanization, global population and economic activity have resulted in a significant rise in the consumption of land over the past 30 years [1]. Reclaiming land from the sea-the production of additional land-has often been the preferred solution in order to meet the demand for more land in support of urban development [1,2]. For example, China extensively reclaimed 11,162.89 $\mathrm{km}^{2}$ of land from the sea between 1979 and 2014, to meet the increasing needs of agriculture, industrialization and urbanization [3]. In particular, Shanghai-the largest city in China-increased its land area by about $728 \mathrm{~km}^{2}$ between 1980 and 2015 by extending the urban built-up area into the ocean [4]. While coastal reclamation is utilized in many countries for promoting socio-economic development, it has also resulted in many negative environmental consequences, such as degradation of the natural coastline, damages to coastal ecosystems, pollution of the marine environment and geological disasters $[5,6]$. 
A coastal reclamation zone is prone to storm tide-induced coastal flooding, due to its low-lying elevation and dense socio-economic and physical exposure, and the compound effects of rapid urbanization and climate change are projected to exacerbate the impacts of coastal floods. It was projected that global mean sea level will continue to rise, approaching $1 \mathrm{~m}$ by the end of the 21st century [7]. Sea-level rise will raise extreme water levels in storm surges, leading to large increases in future overall flood frequency and intensity [8-10]. There is also growing evidence for a future shift in the average global intensity of tropical cyclones, toward stronger storm surges [11]. In addition, socio-economic development is of equal importance in altering coastal flood impacts [12]. Ongoing rapid urbanization is likely to continue in most cities over the next few decades [13], indicating that an overall increasing trend of exposure and vulnerability to coastal flooding can be expected in the future. However, neither current activities nor planned reclamation projects take the risks of extreme coastal flooding into consideration [14]. It is therefore urgent to investigate the influence of the dynamic characteristics of reclamation on coastal flooding, as well as its socio-economic impacts, in order to support the planning, implementation and optimization of measures that can create coastal flood-resilient cities.

There have been an increasing number of studies in the literature focusing on coastal land reclamation. Several seminal studies have analyzed the industrial reclamation, both considering the environmental and the social aspects of reclamations. Loures and Crawford [15] discussed the role of public participation in the post-industrial landscape reclamation of Emscher Park, Germany, and concluded that public participation contributes to achieving sustainable development through improving community consciousness and responsibility. Loures and Panagopoulos [16] analyzed two industrial reclamation projects in Portugal, and highlighted the importance of industrial landscape in developing new multifunctional urban landscapes. More recently, the characteristics of coastal reclamation, including its driving factors and ecological and environmental influences, have been frequently investigated. Yet, few studies have thoroughly analyzed reclamation to identify the dynamics of the coastal hazards it can inflict. With the help of multi-temporal remote sensing data and statistical data, Li et al. [6], Sengupta et al. [1], Wang et al. [17] and Zhang et al. [4] determined the extent of spatial change attributable to coastal land reclamation, and concluded that the area of reclaimed land has been increasing dramatically over the last 40 years. Based on the spatial and temporal distributions of coastal reclamation, Meng et al. [3] and Tian et al. [18], in a further step, evaluated the effects of economic development, population growth, and urbanization rate on coastal reclamation, and found that a booming economy is the main driver of high-intensity coastal reclamation.

Some other previous studies have also emphasized the ecological and environmental impacts of coastal reclamation. Duan et al. [5] and Xue et al. [19] demonstrated the substantial ecosystem-related damages and the deterioration of marine environmental quality in coastal reclamation zones in China, including circulation and siltation, water quality, sediment, the benthic community, and mangrove stands. In particular, reclamation activities have caused massive declines in coastal wetland areas [20,21] and resulted in considerable ecosystem service losses [22,23]. In addition to the ecological and environmental impacts, land reclamation-related geological disasters, such as land subsidence, landslides and related earth movements, have also been reported [24,25]. However, few studies have investigated or discussed the impacts of land reclamation on storm tide-induced coastal flooding. Although Ding and Wei [26], Gao et al. [27] and Song et al. [28] modeled the impact of land reclamation on tidal dynamics and storm surges, the role of reclamation on inundation features and the socio-economic consequences of coastal flooding are still unknown.

Similarly, in the field of coastal flood impact assessment, previous studies have investigated the impact of sea-level rise, socio-economic development, subsidence and land use change on coastal flooding, but failed to include coastal reclamation in their analyses. Benassai et al. [29], Huang et al. [30], Neumann et al. [31] and Rizzi et al. [32] included future sea-level rise scenarios in hazard modeling, to investigate the impact of sea-level rise 
on coastal flood risk, in the Sele plain of Southern Italy, the Red River Delta in Vietnam, and the North Adriatic coast, respectively. Socio-economic factors such as population and gross domestic product (GDP) are widely used in estimating the global economic exposure and population exposure to coastal flooding $[33,34]$. Previous studies also combined different sources to explore their compound effects on coastal flooding and the resulting risk. For instance, Du et al. [35], Wang et al. [36], Yin et al. [37] and Yin et al. [38] modeled the combined impacts of sea-level rise, subsidence and land use changes, and socioeconomic development on coastal flood risk in Shanghai, China. Moreover, the well-known dynamic interactive vulnerability assessment (DIVA) model is widely used to integrate sea-level rise, population growth, economic development and future adaptation measures for the dynamic assessment of coastal flood risk [39-41]. Nevertheless, none of these studies included coastal reclamation as a driving factor of coastal flooding.

Therefore, in this study, by using Xiamen City, China as a case study, we extract the spatiotemporal dynamics of coastal reclamation in order to: (1) identify the influence of historical and future land reclamation on coastal inundation and the consequent population exposure; (2) analyze the future additional impact of sea-level rise on coastal flooding in the reclamation zone; and (3) discuss applicable implications for coastal management and resilient urban land use planning, for adaptation to coastal flooding.

\section{Materials and Methods}

\subsection{Study Area}

Xiamen City, with a $226 \mathrm{~km}$ coastline, is a typical highly urbanized coastal city, located on the southeastern coast of China and adjacent to the East China Sea (Figure 1). Xiamen is designated a Special Economic Zone of China. It has a land area of 1700.6 square kilometers and had a population of 4,290,000 in 2019. Owing to Xiamen's booming economy and rapid urbanization, its coast has been experiencing rapid and intensive land reclamation in order to meet the needs of development [42]. Xiamen is also frequently subjected to coastal flooding from typhoon storm surges, because of its low-lying terrain: the land area with an elevation of less than 10 meters accounts for $16 \%$ of the total area of Xiamen. Historically, Xiamen suffered from 160 coastal flooding events induced by storm surges between 1956 and 2012, with an average frequency of 2.8 times a year, and the average water depth and the highest water depth were $0.33 \mathrm{~m}$ and $4.54 \mathrm{~m}$, respectively. In 1999, a storm surge from Typhoon No. 9914 induced extreme coastal flooding, causing 23 deaths, and was responsible for RMB 1.94 billion in direct economic losses. Given the combination of ongoing and future sea-level rise and rapid socio-economic development, especially in the reclaimed zone, the coastal flood risk facing Xiamen will increase dramatically, indicating an urgent need for understanding future coastal flood risk and the corresponding measures for local adaptation and risk management. 


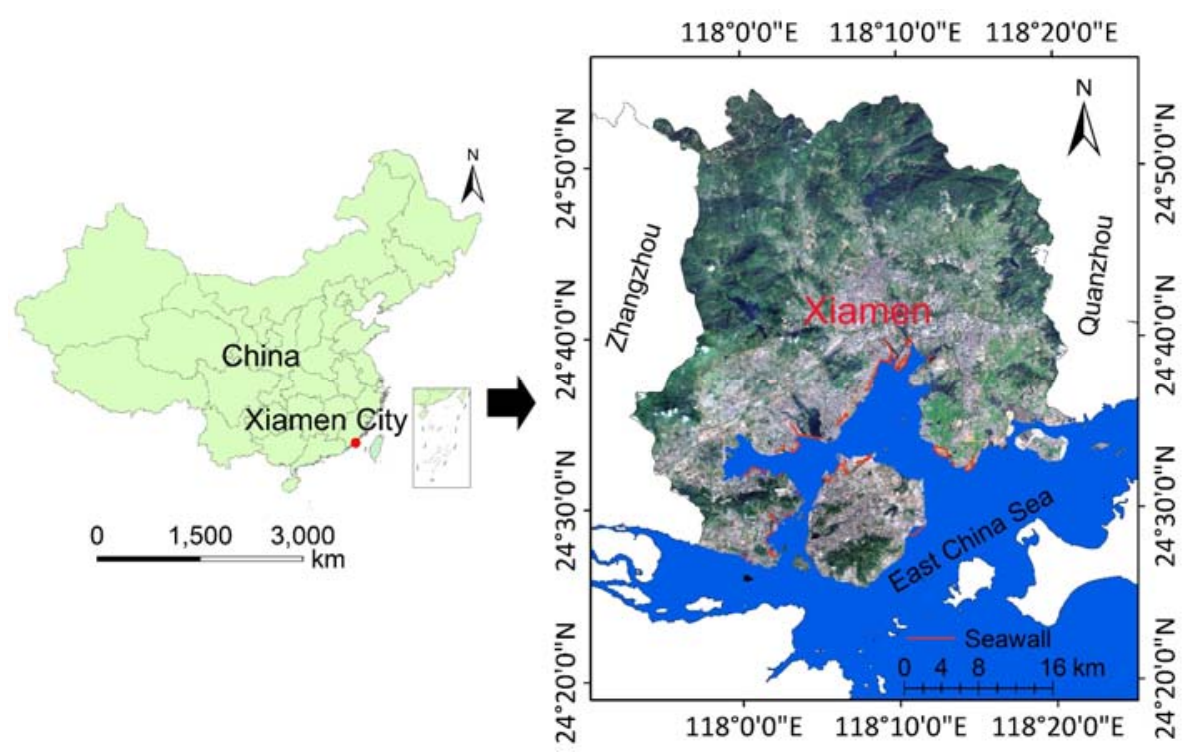

Figure 1. Geographical location and seawall distribution in Xiamen City.

\subsection{Methods}

\subsubsection{Methodology Overview}

Figure 2 shows the overall methodology of the study conducted for incorporating the spatiotemporal dynamics of reclamation into a coastal flood impact model, in order to investigate the long-term influence of reclamation activities on coastal flood inundation and the consequent population exposure.

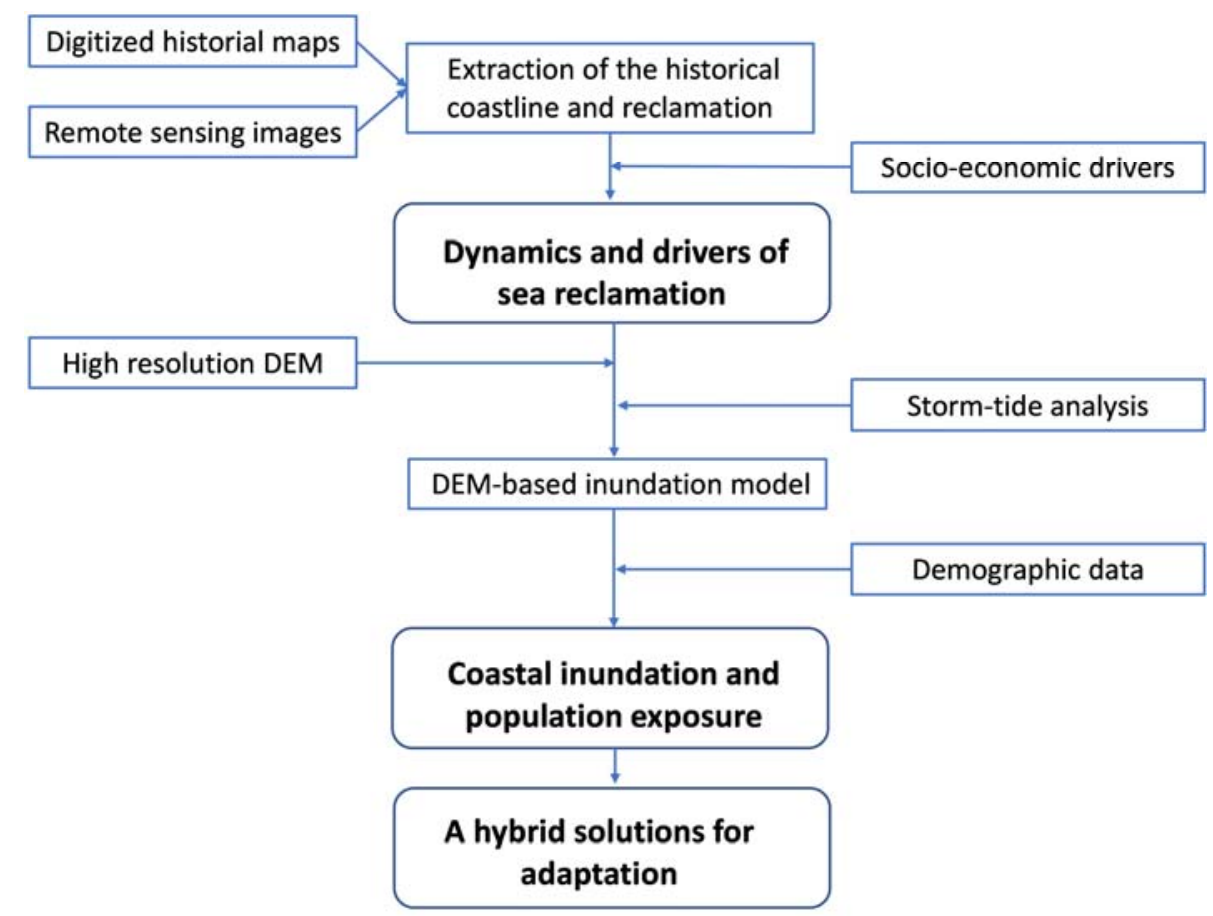

Figure 2. Flowchart showing the methodology of the study.

\subsubsection{Coastline and Land Reclamation Extraction}

In this study, we combine two sources of data for extracting the historical coastline and reclamation: (1) historical maps of Xiamen, after being scanned and digitized, are employed for the extraction of coastline and reclamation data for 1947 and 1960; (2) remote 
sensing images of Xiamen are employed for obtaining coastline and reclamation data for 1972, 1978, 1988, 1997, 2008 and 2017. Detailed descriptions of these data are shown in Table 1.

Table 1. Data descriptions.

\begin{tabular}{cccc}
\hline Data Type & Data & Resolution & Data Source \\
\hline \multirow{2}{*}{ Map } & $\begin{array}{c}\text { Historical maps of Xiamen in } \\
\text { 1947 and 1972 }\end{array}$ & $1: 5000$ & $\begin{array}{c}\text { Xiamen Bureau of Land Resources } \\
\text { and Real Estate Administration, } \\
\text { 2016. Xiamen Atlas }\end{array}$ \\
\hline \multirow{2}{*}{ Remote Sensing Images } & $\begin{array}{c}\text { MSS images in December 1972 } \\
\text { and November 1978 }\end{array}$ & $80 \mathrm{~m}$ & http://glovis.usgs.gov (accessed on \\
& $\begin{array}{c}\text { TM image data in December } \\
\text { 1988 and January 1997 }\end{array}$ & $30 \mathrm{~m}$ & 2019) \\
\cline { 2 - 3 } & SPOT 5 image in January 2007 & $2.50 \mathrm{~m}$ & http://www.gscloud.cn/ (accessed \\
on 13 August 2019)
\end{tabular}

The remote sensing images were pretreated by ENVI 5.2 software, including band synthesis, image clipping, geometric correction, image enhancement, etc. By referring to the methods of Ghaderpour [43] and Karney [44], the digitized historical maps and the sensing images were then adjusted in the same geographic coordinate systems: the WGS-84 coordinate system and universal transverse Mercator projection. With the digital maps and remote sensing images, we adopted the visual interpretation method to manually vectorize the coastline via the ArcGIS 10.2 software platform.

\subsubsection{Coastal Flood Modeling and Exposure Analysis}

Storm surges are a natural phenomenon in which the water level rises abnormally when a storm with low atmospheric pressure and strong winds passes over the sea [45]. If a storm surge coincides with an astronomically high tide, a storm tide may emerge [46]. Based on the long-term tide observation data from 1960 to 2009 at the Gulangyu National Tide Gauge Station, we employed a generalized extreme-value distribution (GEV) to model the storm tide. It should be emphasized that the processes of periodic inundation occurring in low-lying coastal zones due to tidal influences are complex. Tidal surges can carry sediments that could elevate land on low-lying coasts, which could reduce flood potentials [47]. Such a complex coastal process has not been considered in this study, because the sediment deposition due to tide is not clear in Xiamen and there is lack of long-term observation data. In addition, land subsidence has also been proven to alter coastal flooding. According to the National Land Subsidence Prevention Plan (2011-2020) and Xiamen Geological Engineering Investigation Institute, ground subsidence is unlikely to occur because of Xiamen's granite geology with low groundwater reserves, and no uplift has been observed historically. Thus, the vertical land movement was not considered in the study.

Generally, there are two types of approach for coastal flood modeling: a digital elevation model (DEM)-based approach and a hydrodynamic modelling approach. A DEM-based approach is a simple method with a basic assumption: all areas with elevation less than the extreme water level of a given storm tide, and of connectivity to the source of water, are indicated as inundated. There are several drawbacks associated with this method: for example, overestimation of the flooded area due to no volume control, neglect of the effects of dike lines, and the absence of the actual dynamics of the inundation process [48]. A hydrodynamic modelling approach is more sophisticated and can address the disadvantages of the DEM-based model, because it is able to consider the hydraulically important features such as streets, buildings, channels, underground drainage network, etc. [48]. However, it needs a wide range of data, such as the digital surface model, the drainage pipeline data, and more detailed hydrological data. By contrast, the DEM-based 
model is less dependent on data, and its calculation process is faster, and therefore was frequently used in many previous studies. Given the scarcity of the complex dataset required for a hydrodynamic model, here we built a DEM-based approach to simulate the coastal flooding by a storm tide. The DEM with $10 \mathrm{~m}$ resolution was created based on a 1:5000 topographic dataset provided by the Xiamen Municipal Bureau of Land Resources and Real Estate Management. Here, elevation points in the topographic data refer to the Huanghai Height Datum system. The DEM generation and coastal inundation mapping were carried out using ArcGIS software. The coastal inundation is estimated according to the criteria: cells of the DEM that have an elevation value less than or equal to a specified extreme sea level, and have locations adjacent to the sea or are connected to cells of equal or lower elevation that are adjacent to the sea. According to the Flood and Tide Prevention Plan of Xiamen, the current seawalls and levees of Xiamen can only withstand those storm-tide events with a return period of less than 10 years. Thus, we simulated the inundation extents under five extreme sea level events: 10-year, 50-year, 100-year, 200-year, and 500-year return period storm tides. Under these scenarios, seawalls and levees are insufficient to defend against flooding, and hence their effects were not considered.

Regarding the validation of the inundation model, it has been a common problem in current studies, because sufficient data on observed inundation extent are lacking. Given that historically, Xiamen was frequently subjected to storm tide-induced flooding with a return period of about 10 years, the Xiamen Bureau of Water Resources extracted the observed inundation area of a 10-year storm-tide event in Maluan Bay of Xiamen. Therefore, the observed inundation map was compared with the results from inundation modelling, for the validation of the built DEM-based inundation model. As shown in Figure 3, the simulated inundation map fits well with the observed one, with $84.4 \%$ of the inundation area been correctly modeled. This demonstrates an acceptable performance of the built inundation model, and thus is applicable for modeling the inundation extent for other storm tide events.

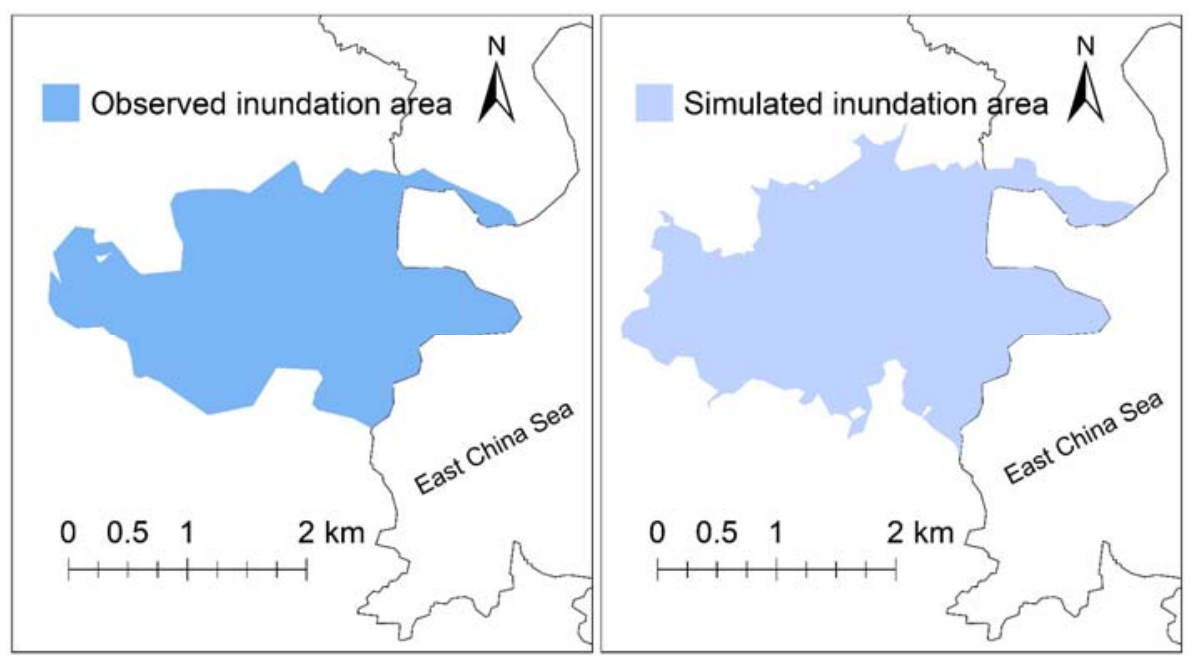

Figure 3. The comparison of the observed inundation map with the simulated inundation area of a 10-year storm-tide event in Muluan Bay of Xiamen.

Population exposure analysis was conducted to determine the extent to which the population will be exposed to the inundation area. Population census data were overlaid with the flood-area map, to extract the population exposed to a given flood event. Finally, the expected annual population (EAP) exposed to coastal flooding was calculated to represent the average value of the population affected in a given year. 


\section{Results}

\subsection{Dynamics and Drivers of Sea Reclamation}

The reclamation area of Xiamen has been increasing continuously, although the speed has varied over different periods of time. The total reclamation area reached $175.49 \mathrm{~km}^{2}$ over the period from 1947 to 2017 (occupying 10.32\% of the current total land area of Xiamen), with an increase rate of $2.28 \mathrm{~km}^{2}$ per year. Due to the massive reclamations for agriculture and aquaculture, the reclamation rate between 1947 and 1972 was highest, reaching $3.26 \mathrm{~km}^{2}$ per year. Reclamation activities from 1972 to 2017 remained relatively stable, with a reclamation rate of around $1.73 \mathrm{~km}^{2}$ per year. During this period, the reclamation area was mainly used for port and airport construction, and for urban expansion. The coastline has also been altered as a consequence of these reclamation activities. As shown in Figure 4, the coastline of Xiamen has been moving toward the sea over the past 70 years. Generally, the coastline shrank from $303.88 \mathrm{~km}$ in 1957 to $222.23 \mathrm{~km}$ in 2017, with a significant decreasing magnitude of $26.87 \%$. Over the long-term dynamic process, the length of the coastline experienced a significant decreasing trend from 1947 to 1978, and thereafter started to increase from 1978 to 2017. From 1947 to 1978, massive reclamations for agriculture and aquaculture enclosed many bays, resulting in a significant reduction in the coastline. By contrast, from 1978 to 2017, urban expansion dominated the process of land reclamation, and caused the coastline to protrude outward, leading to an increase in the coastline.
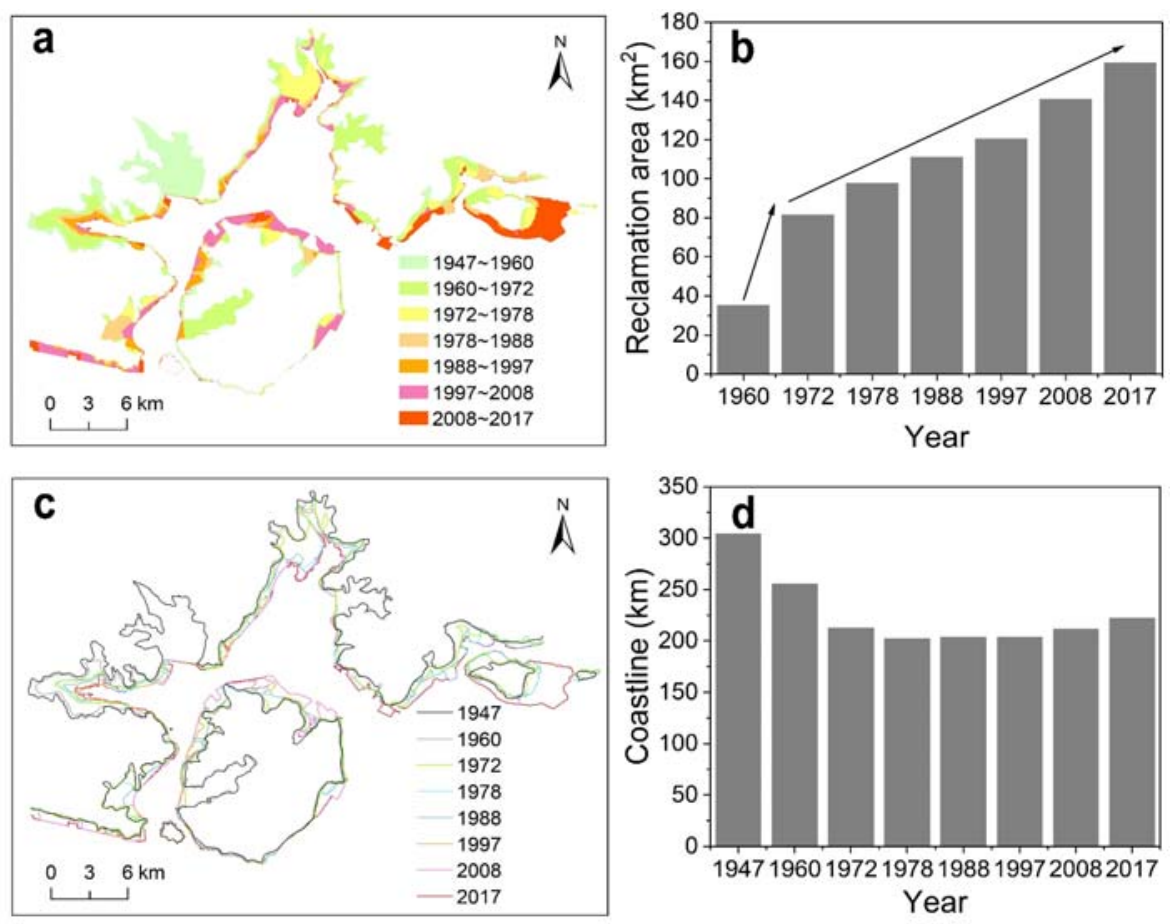

Figure 4. Spatiotemporal dynamics of land reclamation and coastline in Xiamen city from 1947 to 2017: (a) spatial distribution of added reclamation area; (b) statistics of reclamation area (compared to 1947); (c) spatial distributions of coastline; and (d) statistics of coastline.

Here, to further understand the relationship between land reclamation and socioeconomic development, we chose GDP, population, urbanization rate and built-up area to fit with the reclamation area. As shown in Figure 5, all of the urban socio-economic indicators display a statistically significant relationship with land reclamation. This is consistent with the results from Meng et al. [3] and Tian et al. [18]. Notably, the relationships between reclamation and GDP, population, urbanization rate and built-up area are not linear, but reclamation area responds in a logarithmic curve as GDP, population, urbanization rate and urban built-up area rise. Our results imply that in the early stages of urbanization, 
socio-economic development requires relatively more land reclamation, while in the later stages of urbanization, the demand for reclamation from socio-economic development is relatively reduced.
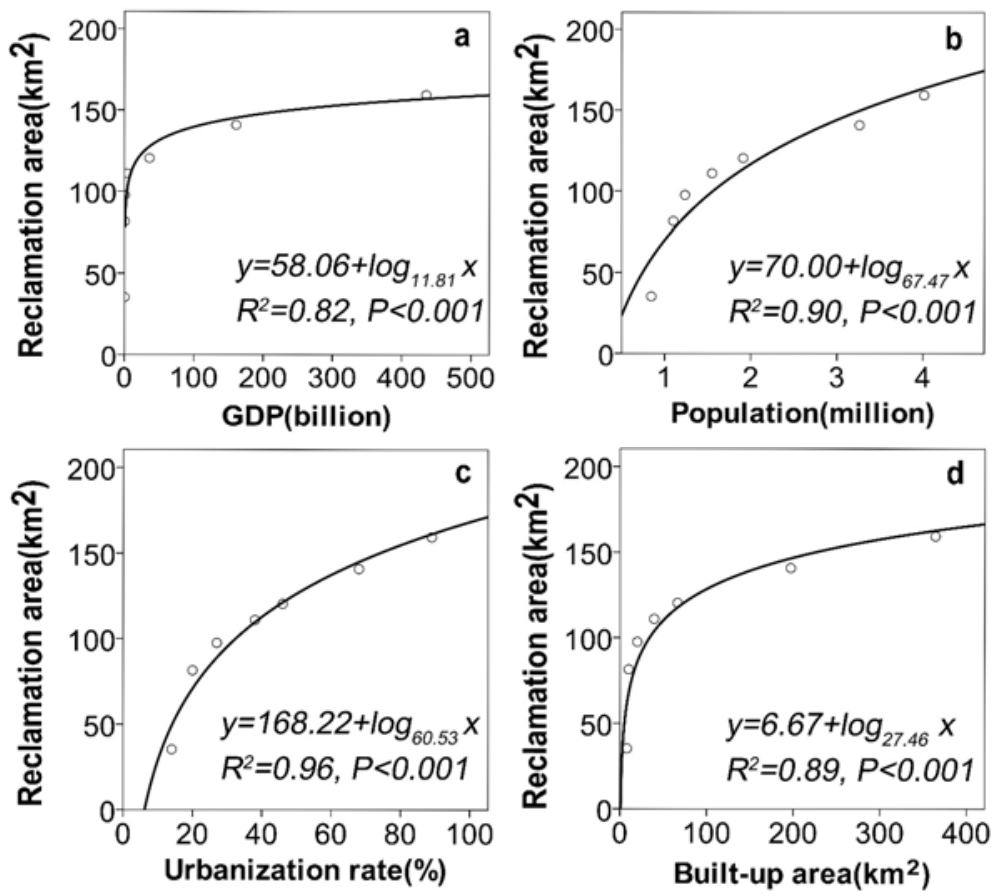

Figure 5. Relationships between land reclamation and (a) GDP, (b) population, (c) urbanization rate, and (d) urban built-up area.

\subsection{Impact of Land Reclamation on Coastal Inundation}

Figure 6 shows the storm tide modeled by GEV, represented in terms of storm-tide height at different return periods. The hazard curve of storm tides fits well with the results provided by the Xiamen Municipal Bureau of Water Resources, implying an acceptable accuracy for our modeling. In this study, we employ five storm-tide events-10-year, 50-year, 100-year, 200-year, and 500-year return period-to model their respective coastal inundation levels and the corresponding expected annual inundation (EAI).

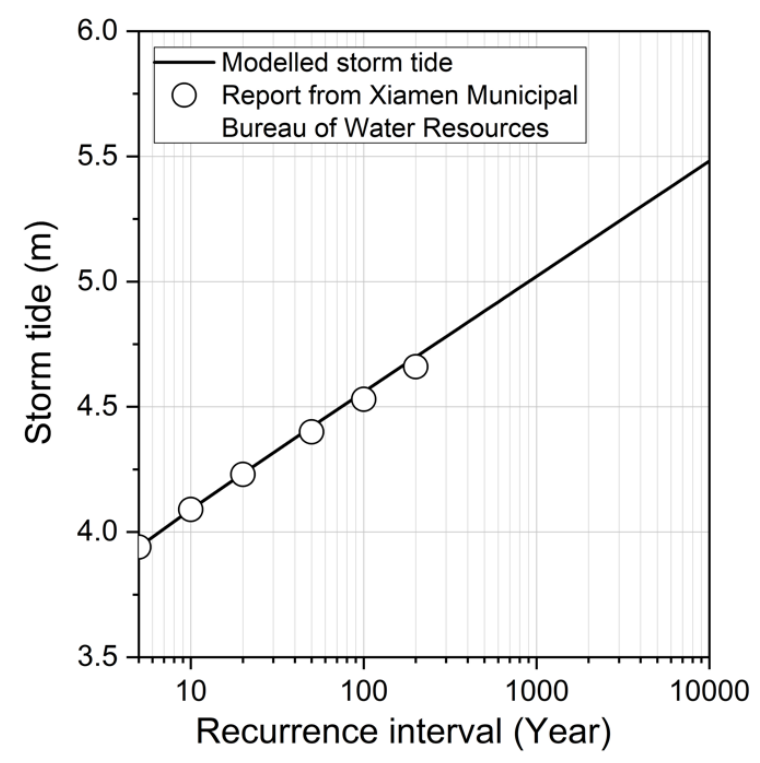

Figure 6. Modelled storm tide at different return periods. 
The inundation hazard maps corresponding to a series of storm-tide events from 1947 to 2017 are shown in Figure 7 (here, we take 10-year, 100-year and 500-year extreme water levels as examples to illustrate the inundation features). Generally, the inundated area under each storm-tide event increases rapidly with the expansion of coastal reclamation from 1947 to 2017. For example, considering a 10-year storm tide-a relatively smaller coastal flooding hazard - the inundated area increased from $21.43 \mathrm{~km}^{2}$ in 1947 to $44.58 \mathrm{~km}^{2}(+108.0 \%)$ in $1960,67.04 \mathrm{~km}^{2}(+212.8 \%)$ in $1972,78.69 \mathrm{~km}^{2}(+267.2 \%)$ in 1978 , $85.25 \mathrm{~km}^{2}(+297.7 \%)$ in $1988,89.80 \mathrm{~km}^{2}(+319.0 \%)$ in $1997,99.81 \mathrm{~km}^{2}(+365.7 \%)$ in 2008 and $118.47 \mathrm{~km}^{2}(+452.8 \%)$ in 2017. In the case of a 500-year storm tide-a relatively larger extreme coastal flooding hazard-the inundated area increased from $39.03 \mathrm{~km}^{2}$ in 1947 to $63.84 \mathrm{~km}^{2}(+63.6 \%)$ in $1960,98.64 \mathrm{~km}^{2}(+152.7 \%)$ in $1972,111.39 \mathrm{~km}^{2}(+185.4 \%)$ in 1978 , $120.31 \mathrm{~km}^{2}(+208.2 \%)$ in $1988,126.58 \mathrm{~km}^{2}(+224.3 \%)$ in $1997,139.51 \mathrm{~km}^{2}(+257.4 \%)$ in 2008 and $159.10 \mathrm{~km}^{2}(+307.6 \%)$ in 2017. The consequent expected annual inundation (EAI) area also exhibits a stable increasing trend: its value increased from $12.33 \mathrm{~km}^{2}$ in 1947 to $25.12 \mathrm{~km}^{2}(+103.7 \%)$ in $1960,38.06 \mathrm{~km}^{2}(+208.6 \%)$ in $1972,44.50 \mathrm{~km}^{2}(+260.9 \%)$ in 1978 , $48.18 \mathrm{~km}^{2}(+290.7 \%)$ in $1988,50.73 \mathrm{~km}^{2}(+311.4 \%)$ in 1997, $56.31 \mathrm{~km}^{2}(+356.7 \%)$ in 2008 and $66.61 \mathrm{~km}^{2}(+440.2 \%)$ in 2017, with an annual average rate of $2.44 \%$ from 1947 to 2017 . In the inundation area of 2017, built-up area is the major land use type, indicating that the urban socio-economic system is subjected to large impacts from coastal flooding.
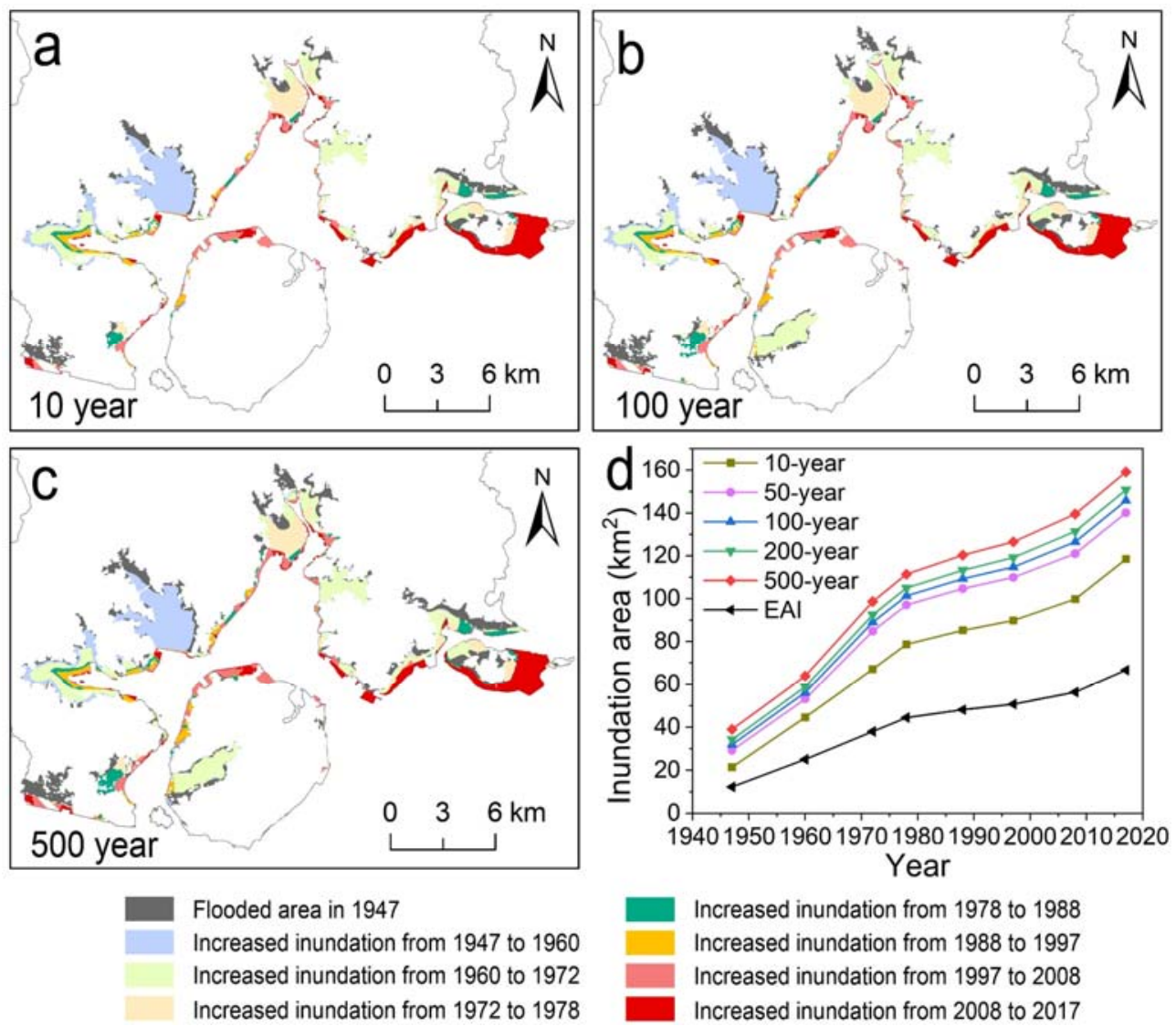

Flooded area in 1947

Increased inundation from 1947 to 1960 Increased inundation from 1960 to 1972 Increased inundation from 1972 to 1978

Figure 7. Spatial distribution and statistics of coastal flooded area at different return periods. (a) Coastal flooded area of a 10-year storm tide event, (b) coastal flooded area of a 100-year storm tide event, (c) coastal flooded area of a 500-year storm tide event, and (d) statistical results of coastal flooded area.

\subsection{Impact of Sea Reclamation on Population Exposure}

Dramatic land reclamation drives the dynamic trend of population exposure to coastal flooding. Figure 8a shows the population exposed to coastal flooding. According to the 
model, the expected annual population (EAP) exposed to coastal flooding was estimated to increase significantly from 1947 to 2017. Additionally, the EAP exposed to coastal flooding has in fact increased sharply, from 4.66 thousand (corresponding to $0.8 \%$ of total population in Xiamen) in 1947 to 165.55 thousand (corresponding to $4.1 \%$ of total population in Xiamen) in 2017. Two major factors contributed to this increase: population growth in the nonreclamation area, and the expansion of the reclamation area accompanied by the consequent population growth it accommodated. Therefore, we further quantitively identified the relative contributions of these two influences on the population exposed to coastal flooding. As depicted in Figure 8b, the growing population in reclamation areas dominates the population exposure, and its relative contribution is increasing, rising from $50.90 \%$ in 1960 to $83.92 \%$ in 2017 . This is consistent with the reality that population and economic activities tend to be concentrated in coastal areas, because of the rapid urbanization there [34].
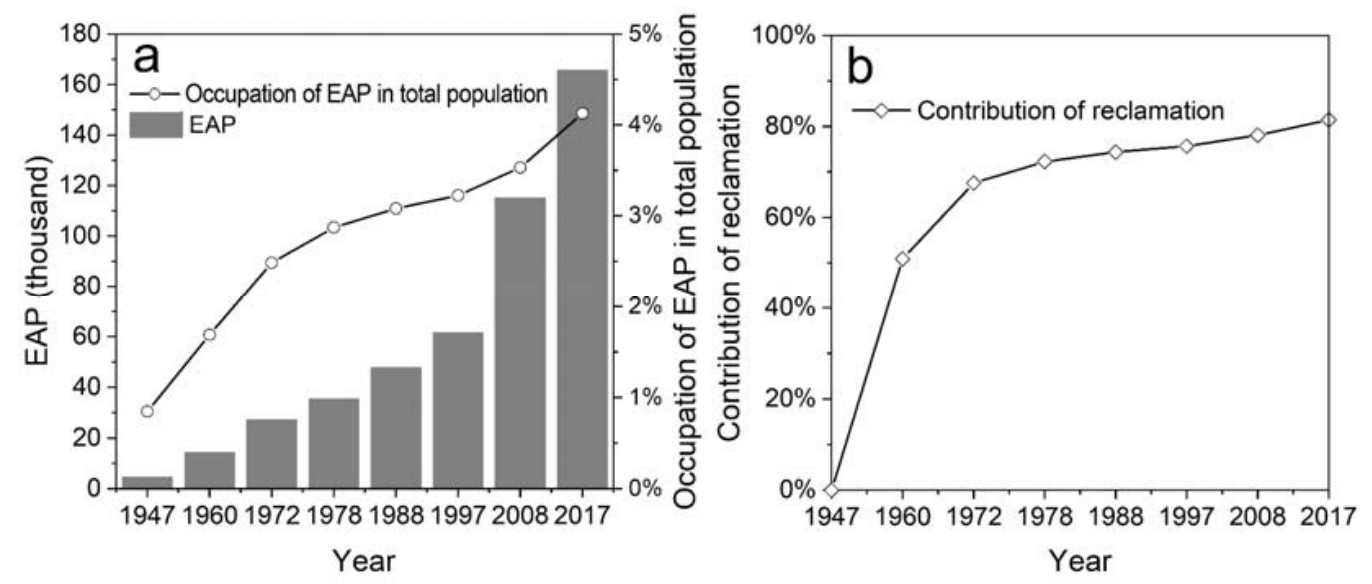

Figure 8. (a) Expected annual population (EPA) exposed to coastal flooding, and (b) the contribution of land reclamation, from 1947 to 2017.

Given that historically, reclamation has substantially increased population exposure, it is essential to incorporate reclamation into the assessment process of future coastal flooding impacts. Previous studies estimated the future population living in coastal flood plains, but failed to incorporate the impact of reclamation. For instance, Fang et al. [49] applied the DIVA model to quantify the potential impacts of coastal flooding in China over the 21st century, and found that 0.7-20.0 million people may be flooded annually by 2100. In a study by Kulp and Strauss [50], the expected annual population exposure in New York City is estimated to rise from 23,700 in 2000 to 206,700 in 2100 under an RCP 8.5 scenario. A study by Neumannet et al. [34] showed that the population living in the 100-year coastal flood plain is estimated to increase from 189 million in 2000 to 411 million by 2060. Although these studies considered future sea-level rise and socio-economic development and demonstrated the increasing trend of future population exposure, coastal land expansion due to reclamation was not considered, and thus we argue that population exposure might have been underestimated in these studies. To demonstrate our argument, we further modeled the future population living in the coastal inundation area of Xiamen by 2035. Based on the Xiamen Master Plan 2017-2035 [51], we extrapolated the additional land reclamation of coastal Xiamen from 2017 to 2035, and in a further step simulated the inundated area and the resulting population exposure. According to our modelling, 83\% of the new reclamation zone is estimated to be episodically flooded in 2035. As shown in Figure 9, EAI will reach $72.52 \mathrm{~km}^{2}-8.88 \%$ more in comparison to the value in 2017 , owing to future continuing land reclamation. In addition, the resulting EAP exposed to inundation is estimated as 266.8 thousand- -1.61 times that of 2017, and new land reclamation from 2017 to 2035 accounts for almost $21.48 \%$ of the increase in future population exposure. Therefore, ignoring coastal reclamation is very likely to lead to underestimates of coastal flood impacts. 

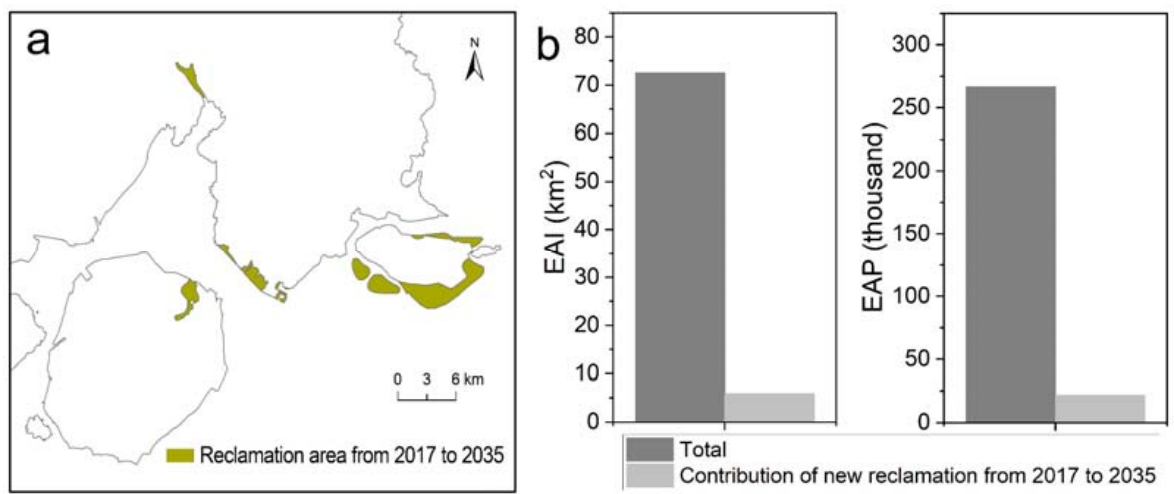

Figure 9. (a) New reclamation area from 2017 to 2035; and (b) expected annual inundation (EAI) and expected annual population (EAP) exposed to coastal flooding in 2035, under the scenario considering future reclamation.

\subsection{Extra Pressures from Future Sea-Level Rise}

In addition to the socio-economic development in both non-reclaimed areas and reclaimed areas, the ongoing and expected accelerating sea-level rise in the future will have substantial influence on coastal flood impacts. Sea-level rise will raise extreme water levels in storm surges, leading to large increases in future overall flood frequency and intensity [8-10]. These influences are expected to exacerbate future coastal flood risk either in isolation or in combination with other factors such as land reclamation. Therefore, we applied a scenariobased analysis to investigate the role of future local sea-level rise in alerting the population living in or relocating to coastal flood plains. According to the China Sea Level Bulletin in 2019, local sea level in 2035 is estimated to rise by up to $10 \mathrm{~cm}$ compared to 2017 [52]. As shown in Figure 10, considering a future $10 \mathrm{~cm}$ sea-level rise, the expected inundation area in 2035 is projected to increase by $5.73 \%$, to $76.67 \mathrm{~km}^{2}$, in comparison to the situation without sea-level rise. As a result, the EAP that will live in the coastal flooded area will also increase, by $8.15 \%$, reaching 282.06 thousand. The extra pressure exerted by sea-level rise is also demonstrated in a study by Hoegh-Guldberg et al. [53], who quantified that an increase of $0.1 \mathrm{~m}$ of SLR will lead to an additional 10 million people being exposed to coastal flooding globally by 2100. In particular, new reclamation zones built from 2017 to 2035 will be those most prone to being affected by sea-level rise, due to their low-lying terrain and geographical proximity to the ocean, and flood impacts in terms of both inundated area and population will also be exacerbated by sea-level rise. For example, a $10 \mathrm{~cm}$ sea-level rise is expected to cause $23.80 \%$ of new reclamation zones to be permanently submerged.

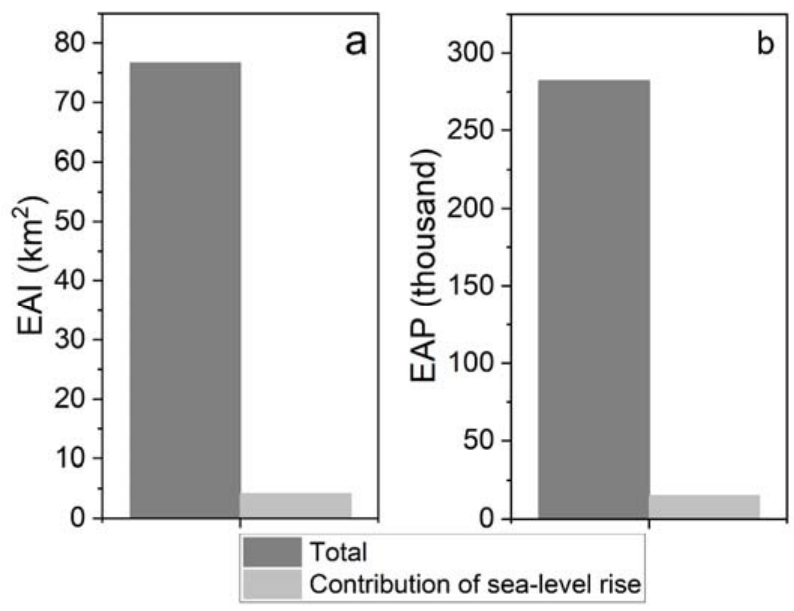

Figure 10. Extra impacts of a future $10 \mathrm{~cm}$ sea-level rise on coastal flooding. (a) Expected annual inundation (EAI), and (b) expected annual population (EAP) exposed to coastal flooding in 2035. 


\section{Discussion}

\subsection{Explanation of Results}

Our long-term analysis helps to reveal the spatiotemporal dynamics of coastal reclamation and its influences on coastal flood inundation and population exposure. As demonstrated in our case study, continuing reclamation activities drive dramatic increases in coastal inundation area. Jongman et al. [33] and Small and Nicholls [54] found that the population growth in flood-prone zones is higher than the average population growth in the hinterland. This effectively explains our findings that, with the increase in coastal inundated area, the population exposed to coastal floods over the period of 1947-2017 also increased exponentially, and can be mainly attributed to population growth in reclamation zones. With respect to future coastal flood impacts, reclamation is also an important contributor, and excluding it will lead to an underestimate of coastal flood impacts. Of particular concern is the influence of future sea-level rise, since, as demonstrated in our case study, it can exacerbate the coastal inundated area and exposed population, particularly in the reclamation zones. This result corresponds with the studies of Neumann et al. [31], Wang et al. [55], Xu et al. [45] and Zimmermann et al. [56], who also investigated the impact of sea-level rise on coastal flooding, and found that sea-level rise could lead to an increase in coastal flood frequency and, in addition, land, population, GDP, buildings and infrastructure being exposed to inundation.

\subsection{Implications for Coastal Flood Resilience and Adaptation}

Understanding and characterizing both current and future impacts of reclamation on coastal flood hazards and its socio-economic consequences are essential for mitigating and adapting to coastal flood hazards, in the context of rapid urbanization and climate change. Given the dramatic increases in inundated area and exposed population induced by reclamation, and additional significant pressures from future sea-level rise, a hybrid approach for adaptation is necessary. On the one hand, hard solutions, that describe the installation of engineering measures to limit or stop natural processes of coastal flooding, are needed to offset threats from sea-level rise and climate change. Generally, protection strategies, such as the construction of more substantial seawalls, dikes, revetments, groynes and breakwaters, and accommodation strategies, such as elevating buildings, and updating drainage systems, are widely used hard solutions. On the other hand, soft solutions, which involve the use of urban planning, more natural methods and policy-related management to reduce the effects of coastal flooding, should be implemented. In particular, smart urban growth in the reclamation zone, via land use planning and design, and nature-based solutions should be emphasized. Hybrid solutions are not only effective to combat coastal flooding, but also contribute to coastal sustainability. Figure 11 depicts the combination of hard solutions with soft solutions, and its contributions to sustainability.

With respect to smart growth in reclamation zones, climate hazard-resilient land use planning and urban form design are effective for coastal flood risk reduction [57]. Given the massive impacts of reclamation on coastal exposure, optimizing land use planning and design is critically important for reducing coastal flood risk. It has been proved that landscape can affect flood area, rate and duration, and socio-economic systems and physical systems exposed to flood also differ among land use types [58,59]. Therefore, in an inundation area, urban sprawl should be strictly prohibited, and new construction land should be allocated in the relatively safe areas of lower hazard severity in terms of inundation depth, duration and flow rate. Moreover, low-density zoning in the coastal floodplain has been proved to decease exposure to flooding, and should thus be encouraged [60]. 


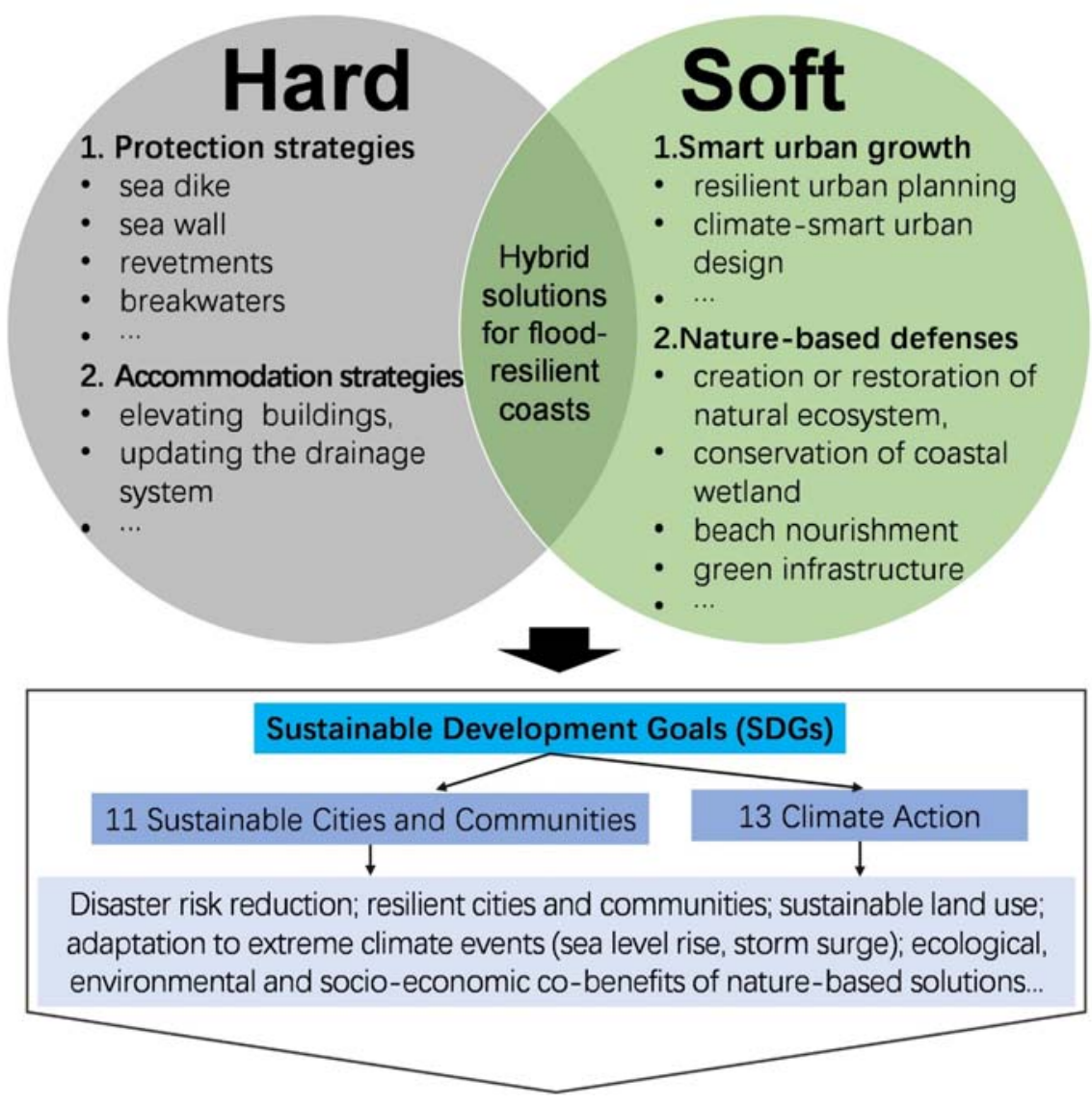

Figure 11. Hybrid approach for coastal flood resilience and adaptation. Our results suggest the importance of integrating both hard solutions and soft solutions for combating coastal flooding. Traditional hard defenses can be constructed in shorter timeframes, and take effect immediately. Soft solutions, such as nature-based coastal defenses, on the other hand, are more cost-effective, sustainable and eco-friendly. The hybrid approach is highly related to coastal sustainability, by contributing to the "climate actions" and "sustainable cities and communities" of the Sustainable Development Goals (SDGs).

In addition, current coastal wetlands and blue and green space must be well protected, managed and restored to maximize their functions as key 'nature-based solutions.' The previous literature has demonstrated that nature-based solutions mitigate flood risk generally in two ways: (1) they avoid the placement of people and structures in the most flood-prone areas, reducing the chances for property loss and economic disruption [61]; and (2) they provide critical and diverse ecosystem services within a floodplain, enabling a substantial reduction in surface water run-off and storm waves, and effective accommodation of longterm sea-level rise [56,62]. As revealed by Arkema et al. [63], fully intact coastal wetlands are estimated to reduce the population and property exposed to future storm surges and sea-level rise in the United States by 2100 by almost half. However, as demonstrated by Beck et al. [64], the annual anticipated global losses from coastal flooding would double if global coral reefs disappear. Del Valle et al. [65] and Sun and Carson [66] revealed that coastal wetlands such as wide mangrove belts are capable of mitigating losses in economic activity and reducing property damage during tropical cyclone-induced coastal flooding. However, as we demonstrated here, the shrinking of the coastline of Xiamen has led to the degradation of coastal wetlands. As shown in Figure 12, natural mangrove stands in coastal Xiamen have shrunk dramatically, with the area declining from $320 \mathrm{hm}^{2}$ in 1960 to $21 \mathrm{hm}^{2}$ in 2020 [67,68]. During the dynamic process of coastline changes, the natural coastline has been replaced by a man-made coastline, transforming it from wetlands (e.g., mangrove stands, saltmarshes, dunes and beaches) to urban impervious surfaces, a shift leading to 
great disadvantages for adapting to coastal floods. Therefore, it is critically important for coastal cities such as Xiamen to conserve and recover coastal wetlands and green open space, and make full use of them in combating coastal flooding, since 'nature-based coastal defenses' are a more cost-effective, sustainable and ecologically sensitive alternative to traditional coastal defense.

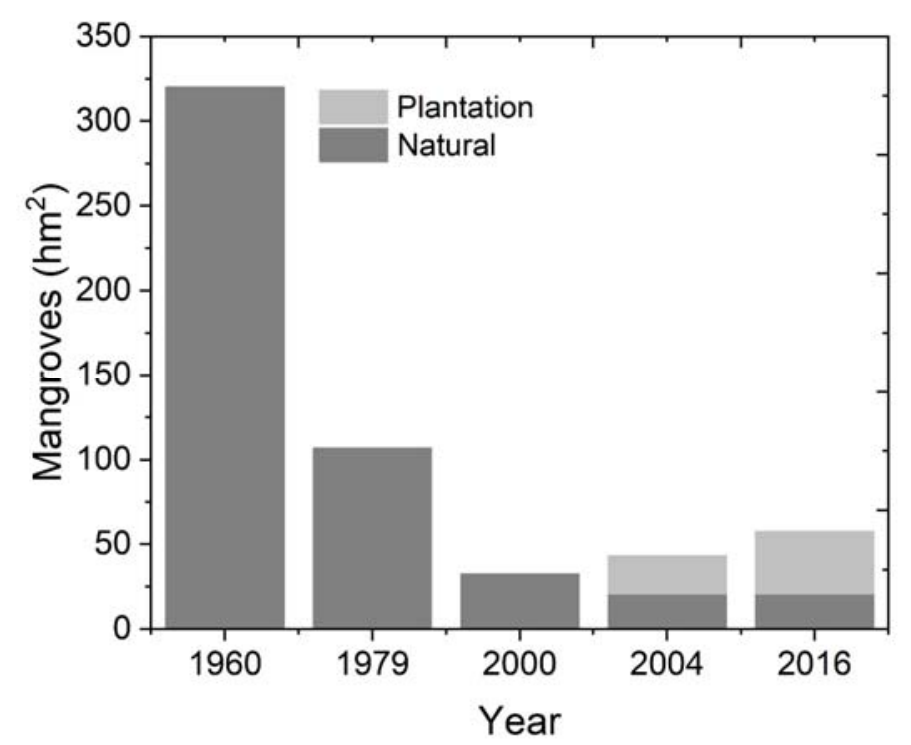

Figure 12. Historical changes in mangrove area in coastal Xiamen from 1960 to 2016, including both natural and plantation mangroves.

With increasingly intense storms and rising sea levels associated with climate change, coastal cities should also build robust hard structures to protect low-lying coastal communities against coastal flooding. A sustainable hard-structure system, consisting of sea walls, dikes and drainage systems, etc., can be completed within shorter timeframes in order to provide a coastal defense solution, and may be suitable when the urgency of asset protection is high [69]. Successful engineering solutions can effectively reduce the coastal flood risks regarding hazard, exposure and vulnerability, as is urgently demanded in urban planning. Hinkel et al. [41] quantified the effects of enhanced dikes on global coastal flood damage under the conditions of 21st century sea-level rise, and found that, compared to the current protection scenario, enhanced protection will reduce coastal flood impacts by about $2-3$ orders of magnitude in 2100 . This study only assessed the coastal inundation extent and the consequent population exposure without considering future enhancement of adaptation. The future state of flood risk-reducing measures should be included in future research. Overall, climate-resilient coastal protection outcomes require a combination of 'nature-based solutions' and hard structures.

\subsection{Limitations}

While this study expands our understanding of the role of land reclamation in altering coastal flooded area and population, it also labors under several limitations that future research needs to address. First, although the performance of our DEM-based inundation model was well validated before it was used for coastal flood modelling, there are a wide range of uncertainties in terms of topography data, coastal sediments due to tide, flood prevention measures, etc. Further studies thus need to take these uncertainties into account to simulate the complex processes of coastal inundation and arrive at the results closer to reality, with the application of more advanced approaches, such as the hydrodynamic models. Second, to explore the impacts of reclamation on coastal flooding, we assumed other driving factors to be static. For instance, changes in the intensity and frequency of storm tides were not included in our analysis, since there is great uncertainty with 
respect to how storm tide activity changes at the local scale because the observational records are insufficient to establish a definitive trend of change in the frequency and intensity of storm tides. Moreover, some other factors, such as coastal subsidence and landscape changes, were also not considered in our study. Future research should focus on incorporating diverse sources of driving factors and their dynamics, in order to investigate their compound effects and relative importance on coastal flooding. Third, as seen in many previous studies, here we employed only population exposure as an indicator to quantify coastal flood impacts, while other elements in urban systems-including buildings, infrastructure and economic activities-are also prone to being affected by coastal flooding. Therefore, it is of substantial significance to incorporate more physical and socio-economic indicators into coastal flood impact assessment, so as to reveal the more comprehensive impacts of reclamation on coastal flooding in terms of exposure, vulnerability, loss and risk.

\section{Conclusions}

Here, we provide a novel empirical study, incorporating the historical and future dynamics of land reclamation into coastal flood modeling, and investigating the influence of reclamation activities on coastal flood inundation and population exposure, in order to elevate the importance of better reclamation planning for resilient coasts. As demonstrated by a case study of Xiamen, China, coastal reclamation associated with rapid socio-economic growth and urbanization has increased substantially and led to dramatic changes in coastlines. Historical expansion of reclamation zones has continuously caused significant increases in the inundation area and population exposed to storm tide-induced coastal flooding. Furthermore, future reclamation is expected to continue to drive an increase in coastal flood impacts. These alarming facts indicate that ignoring reclamation is very likely to cause serious underestimates of coastal flood impacts. Sea-level rise is another variable that should also be emphasized, since it can intensify coastal flooding and lead to further inundation and population exposure, especially since portions of the new reclamation zones are estimated to be permanently submerged, as we demonstrated in this study. Based on our analysis, we recommend developing a hybrid solution for coast flood resilience and adaptation, namely conserving and restoring coastal wetlands as nature-based solutions for combating coastal flooding, while also building hard engineering structures for offsetting extra pressures from future sea-level rise or any other climate-change factors.

Author Contributions: Conceptualization, L.X. and J.T.; methodology, L.X.; software, S.D.; validation, L.X., S.D. and J.T.; formal analysis, L.X., V.N., S.D. and J.T.; investigation, L.X.; resources, L.X.; data curation, L.X.; writing-original draft preparation, L.X.; writing-review and editing, V.N.; visualization, S.D.; supervision, L.X. and J.T.; project administration, L.X. All authors have read and agreed to the published version of the manuscript.

Funding: This research was funded by the National Key Research and Development Program of China (2019YFC1510704), The National Natural Science Foundation of China (42007418), and The Fujian Provincial Natural Science Foundation (2019J05160).

Conflicts of Interest: The authors declare no conflict of interest.

\section{References}

1. Sengupta, D.; Chen, R.; Meadows, M.E. Building beyond land: An overview of coastal land reclamation in 16 global megacities. Appl. Geogr. 2018, 90, 229-238. [CrossRef]

2. Lai, L.W.C.; Chau, K.W.; Lorne, F.T. "Forgetting by not doing": An institutional memory inquiry of forward planning for land production by reclamation. Land Use Policy 2019, 82, 796-806. [CrossRef]

3. Meng, W.; Hu, B.; He, M.; Liu, B.; Mo, X.; Li, H.; Wang, Z.; Zhang, Y. Temporal-spatial variations and driving factors analysis of coastal reclamation in China. Estuar. Coast. Shelf Sci. 2017, 191, 39-49. [CrossRef]

4. Zhang, Y.; Chen, R.; Wang, Y. Tendency of land reclamation in coastal areas of Shanghai from 1998 to 2015. Land Use Policy 2020, 91, 104370. [CrossRef]

5. Duan, H.; Zhang, H.; Huang, Q.; Zhang, Y.; Hu, M.; Niu, Y.; Zhu, J. Characterization and environmental impact analysis of sea land reclamation activities in China. Ocean Coast. Manag. 2016, 130, 128-137. [CrossRef] 
6. $\quad$ Li, F.; Ding, D.; Chen, Z.; Chen, H.; Shen, T.; Wu, Q.; Zhang, C. Change of sea reclamation and the sea-use management policy system in China. Mar. Policy 2020, 115, 103861. [CrossRef]

7. Stocker, T. Climate Change 2013: The Physical Science Basis: Working Group I Contribution to the Fifth Assessment Report of the Intergovernmental Panel on Climate Change; Cambridge University Press: Cambridge, UK, 2014.

8. Garner, A.J.; Mann, M.E.; Emanuel, K.A.; Kopp, R.E.; Lin, N.; Alley, R.B.; Horton, B.P.; DeConto, R.M.; Donnelly, J.P.; Pollard, D. Impact of climate change on New York City's coastal flood hazard: Increasing flood heights from the preindustrial to $2300 \mathrm{CE}$. Proc. Natl. Acad. Sci. USA 2017, 114, 11861-11866. [CrossRef]

9. Marsooli, R.; Lin, N.; Emanuel, K.; Feng, K. Climate change exacerbates hurricane flood hazards along US Atlantic and Gulf Coasts in spatially varying patterns. Nat. Commun. 2019, 10, 3785. [CrossRef] [PubMed]

10. Vousdoukas, M.I.; Mentaschi, L.; Voukouvalas, E.; Bianchi, A.; Dottori, F.; Feyen, L. Climatic and socioeconomic controls of future coastal flood risk in Europe. Nat. Clim. Chang. 2018, 8, 776-780. [CrossRef]

11. Knutson, T.R.; McBride, J.L.; Chan, J.; Emanuel, K.; Holland, G.; Landsea, C.; Held, I.; Kossin, J.P.; Srivastava, A.K.; Sugi, M. Tropical cyclones and climate change. Nat. Geosci. 2010, 3, 157-163. [CrossRef]

12. Peduzzi, P.; Chatenoux, B.; Dao, H.; De Bono, A.; Herold, C.; Kossin, J.; Mouton, F.; Nordbeck, O. Global trends in tropical cyclone risk. Nat. Clim. Chang. 2012, 2, 289-294. [CrossRef]

13. Forman, R.T.T.; Wu, J.G. Where to put the next billion people. Nature 2016, 537, 608-611. [CrossRef] [PubMed]

14. Woodruff, J.D.; Irish, J.L.; Camargo, S.J. Coastal flooding by tropical cyclones and sea-level rise. Nature 2013, 504, 44-52. [CrossRef] [PubMed]

15. Loures, L.; Crawford, P. Democracy in progress: Using public participation in post-industrial landscape (re)-development. WSEAS Trans. Environ. Dev. 2008, 4, 794-803.

16. Loures, L.; Panagopoulos, T. Reclamation of derelict industrial land in Portugal: Greening is not enough. Int. J. Sustain. Dev. Plan. 2010, 5, 343-350. [CrossRef]

17. Wang, X.G.; Su, F.Z.; Zhang, J.J.; Cheng, F.; Hu, W.Q.; Ding, Z. Construction land sprawl and reclamation in the Johor River Estuary of Malaysia since 1973. Ocean Coast. Manag. 2019, 171, 87-95. [CrossRef]

18. Tian, B.; Wu, W.; Yang, Z.; Zhou, Y. Drivers, trends, and potential impacts of long-term coastal reclamation in China from 1985 to 2010. Estuar. Coast. Shelf Sci. 2016, 170, 83-90. [CrossRef]

19. Xue, X.; Hong, H.; Charles, A.T. Cumulative environmental impacts and integrated coastal management: The case of Xiamen, China. J. Environ. Manage. 2004, 71, 271-283. [CrossRef]

20. Sousa, C.A.M.; Cunha, M.E.; Ribeiro, L. Tracking 130 years of coastal wetland reclamation in Ria Formosa, Portugal: Opportunities for conservation and aquaculture. Land Use Policy 2020, 94, 104544. [CrossRef]

21. Wu, W.; Yang, Z.; Tian, B.; Huang, Y.; Zhou, Y.; Zhang, T. Impacts of coastal reclamation on wetlands: Loss, resilience, and sustainable management. Estuar. Coast. Shelf Sci. 2018, 210, 153-161. [CrossRef]

22. Ewers Lewis, C.J.; Baldock, J.A.; Hawke, B.; Gadd, P.S.; Zawadzki, A.; Heijnis, H.; Jacobsen, G.E.; Rogers, K.; Macreadie, P.I. Impacts of land reclamation on tidal marsh 'blue carbon' stocks. Sci. Total Environ. 2019, 672, 427-437. [CrossRef]

23. Slamet, N.S.; Dargusch, P.; Aziz, A.A.; Wadley, D. Mangrove vulnerability and potential carbon stock loss from land reclamation in Jakarta Bay, Indonesia. Ocean Coast. Manag. 2020, 195, 105283. [CrossRef]

24. China Daily News. Land Reclamation from Sea Worthwhile? Available online: http://www.chinadaily.com.cn/bizchina/2010-0 6/26/content_10024448.htm (accessed on 1 February 2021).

25. Nanfang Metropolis Daily News. A Serious Foundation Pit Slope Sliding Accident Resulted from the Soft Soil—A Construction Site at Qianhai Zone in Shenzhen. Available online: http://sz.house.qq.com/a/20150712/008933_1.htm (accessed on 3 February 2021).

26. Ding, Y.; Wei, H. Modeling the impact of land reclamation on storm surges in Bohai Sea, China. Nat. Hazards 2017, 85, 559-573. [CrossRef]

27. Gao, G.D.; Wang, X.H.; Bao, X.W. Land reclamation and its impact on tidal dynamics in Jiaozhou Bay, Qingdao, China. Estuar. Coast. Shelf Sci. 2014, 151, 285-294. [CrossRef]

28. Song, D.; Wang, X.H.; Zhu, X.; Bao, X. Modeling studies of the far-field effects of tidal flat reclamation on tidal dynamics in the East China Seas. Estuar. Coast. Shelf Sci. 2013, 133, 147-160. [CrossRef]

29. Benassai, G.; Di Paola, G.; Aucelli, P.P.C. Coastal risk assessment of a micro-tidal littoral plain in response to sea level rise. Ocean Coast. Manag. 2015, 104, 22-35. [CrossRef]

30. Huang, Z.; Zong, Y.; Zhang, W. Coastal Inundation due to Sea Level Rise in the Pearl River Delta, China. Nat. Hazards 2004, 33, 247-264. [CrossRef]

31. Neumann, J.E.; Emanuel, K.A.; Ravela, S.; Ludwig, L.C.; Verly, C. Risks of Coastal Storm Surge and the Effect of Sea Level Rise in the Red River Delta, Vietnam. Sustainability 2015, 7, 6553-6572. [CrossRef]

32. Rizzi, J.; Torresan, S.; Zabeo, A.; Critto, A.; Tosoni, A.; Tomasin, A.; Marcomini, A. Assessing storm surge risk under future sea-level rise scenarios: A case study in the North Adriatic coast. J. Coast. Conserv. 2017, 21, 453-471. [CrossRef]

33. Jongman, B.; Ward, P.J.; Aerts, J.C.J.H. Global exposure to river and coastal flooding: Long term trends and changes. Glob. Environ. Chang 2012, 22, 823-835. [CrossRef]

34. Neumann, B.; Vafeidis, A.T.; Zimmermann, J.; Nicholls, R.J. Future Coastal Population Growth and Exposure to Sea-Level Rise and Coastal Flooding-A Global Assessment. PLoS ONE 2015, 10, e0118571. [CrossRef] 
35. Du, S.; Scussolini, P.; Ward, P.J.; Zhang, M.; Wen, J.; Wang, L.; Koks, E.; Diaz-Loaiza, A.; Gao, J.; Ke, Q.; et al. Hard or soft flood adaptation? Advantages of a hybrid strategy for Shanghai. Glob. Environ. Chang. 2020, 61, 102037. [CrossRef]

36. Wang, J.; Gao, W.; Xu, S.; Yu, L. Evaluation of the combined risk of sea level rise, land subsidence, and storm surges on the coastal areas of Shanghai, China. Clim. Chang. 2012, 115, 537-558. [CrossRef]

37. Yin, J.; Yin, Z.-e.; Hu, X.-m.; Xu, S.-y.; Wang, J.; Li, Z.-h.; Zhong, H.-d.; Gan, F.-b. Multiple scenario analyses forecasting the confounding impacts of sea level rise and tides from storm induced coastal flooding in the city of Shanghai, China. Environ. Earth Sci. 2011, 63, 407-414. [CrossRef]

38. Yin, J.; Yu, D.; Yin, Z.; Wang, J.; Xu, S. Modelling the combined impacts of sea-level rise and land subsidence on storm tides induced flooding of the Huangpu River in Shanghai, China. Clim. Chang. 2013, 119, 919-932. [CrossRef]

39. Diaz, D.B. Estimating global damages from sea level rise with the Coastal Impact and Adaptation Model (CIAM). Clim. Chang. 2016, 137, 143-156. [CrossRef]

40. Tamura, M.; Kumano, N.; Yotsukuri, M.; Yokoki, H. Global assessment of the effectiveness of adaptation in coastal areas based on RCP/SSP scenarios. Clim. Chang. 2019, 152, 363-377. [CrossRef]

41. Hinkel, J.; Lincke, D.; Vafeidis, A.T.; Perrette, M.; Nicholls, R.J.; Tol, R.S.J.; Marzeion, B.; Fettweis, X.; Ionescu, C.; Levermann, A. Coastal flood damage and adaptation costs under 21st century sea-level rise. Proc. Natl. Acad. Sci. USA 2014, 111, $3292-3297$. [CrossRef] [PubMed]

42. Peng, B.; Lin, C.; Jin, D.; Rao, H.; Jiang, Y.; Liu, Y. Modeling the total allowable area for coastal reclamation: A case study of Xiamen, China. Ocean Coast. Manag. 2013, 76, 38-44. [CrossRef]

43. Ghaderpour, E. Some Equal-area, Conformal and Conventional Map Projections: A Tutorial Review. J. Appl. Geod. 2016, 10, 197-209. [CrossRef]

44. Karney, C.F.F. Transverse Mercator with an accuracy of a few nanometers. J. Geod. 2011, 85, 475-485. [CrossRef]

45. Xu, L.; He, Y.; Huang, W.; Cui, S. A multi-dimensional integrated approach to assess flood risks on a coastal city, induced by sea-level rise and storm tides. Environ. Res. Lett. 2016, 11, 014001.

46. McFadden, L.; Spencer, T.; Nicholls, R.J. Broad-scale modelling of coastal wetlands: What is required? Hydrobiologia 2007, 577, 5-15. [CrossRef]

47. Adnan, M.S.G.; Talchabhadel, R.; Nakagawa, H.; Hall, J.W. The potential of Tidal River Management for flood alleviation in South Western Bangladesh. Sci. Total Environ. 2020, 731, 138747. [CrossRef]

48. Apel, H.; Aronica, G.T.; Kreibich, H.; Thieken, A.H. Flood risk analyses-how detailed do we need to be? Nat. Hazards 2009, 49,79-98. [CrossRef]

49. Fang, J.; Lincke, D.; Brown, S.; Nicholls, R.J.; Wolff, C.; Merkens, J.-L.; Hinkel, J.; Vafeidis, A.T.; Shi, P.; Liu, M. Coastal flood risks in China through the 21st century-an application of DIVA. Sci. Total Environ. 2020, 704, 135311. [CrossRef]

50. Kulp, S.; Strauss, B.H. Rapid escalation of coastal flood exposure in US municipalities from sea level rise. Clim. Chang. 2017, 142, 477-489. [CrossRef]

51. Xiamen Municipal Bureau of Nature Resoureces and Planning. Xiamen Master Planning 2017-2035. Available online: http: //zygh.xm.gov.cn/zwgk/zdxxgk/ghcg/ztgh/202001/t20200113_2499452.htm (accessed on 12 October 2020).

52. Ministry of Natural Resources, PRC. 2019 China Sea Level Bulletin. Available online: http://gi.mnr.gov.cn/202004/t20200430_25 10978.html (accessed on 21 December 2020).

53. Hoegh-Guldberg, O.; Jacob, D.; Taylor, M.; Bolaños, T.G.; Bindi, M.; Brown, S.; Camilloni, I.A.; Diedhiou, A.; Djalante, R.; Ebi, K. The human imperative of stabilizing global climate change at $1.5^{\circ} \mathrm{C}$. Science 2019, 365, eaaw6974. [CrossRef]

54. Small, C.; Nicholls, R.J. A global analysis of human settlement in coastal zones. J. Coast. Res. 2003, 584-599.

55. Wang, W.; Liu, H.; Li, Y.; Su, J. Development and management of land reclamation in China. Ocean Coast. Manag. 2014, 102, 415-425. [CrossRef]

56. Zimmermann, E.; Bracalenti, L.; Piacentini, R.; Inostroza, L. Urban flood risk reduction by increasing green areas for adaptation to climate change. Procedia Eng. 2016, 161, 2241-2246. [CrossRef]

57. Xu, L.; Wang, X.; Liu, J.; He, Y.; Tang, J.; Nguyen, M.; Cui, S. Identifying the trade-offs between climate change mitigation and adaptation in urban land use planning: An empirical study in a coastal city. Environ. Int. 2019, 133, 105162. [CrossRef] [PubMed]

58. Bilskie, M.; Hagen, S.; Medeiros, S.; Passeri, D. Dynamics of sea level rise and coastal flooding on a changing landscape. Geophys. Res. Lett. 2014, 41, 927-934. [CrossRef]

59. Lentz, E.E.; Thieler, E.R.; Plant, N.G.; Stippa, S.R.; Horton, R.M.; Gesch, D.B. Evaluation of dynamic coastal response to sea-level rise modifies inundation likelihood. Nat. Clim. Chang. 2016, 6, 696-700. [CrossRef]

60. Viguié, V.; Hallegatte, S. Trade-offs and synergies in urban climate policies. Nat. Clim. Chang. 2012, 2, 334-337. [CrossRef]

61. Brody, S.D.; Highfield, W.E. Open space protection and flood mitigation: A national study. Land Use Policy 2013, 32, 89-95. [CrossRef]

62. Brody, S.D.; Zahran, S.; Highfield, W.E.; Grover, H.; Vedlitz, A. Identifying the impact of the built environment on flood damage in Texas. Disasters 2008, 32, 1-18. [CrossRef]

63. Arkema, K.K.; Guannel, G.; Verutes, G.; Wood, S.A.; Guerry, A.; Ruckelshaus, M.; Kareiva, P.; Lacayo, M.; Silver, J.M. Coastal habitats shield people and property from sea-level rise and storms. Nat. Clim. Chang. 2013, 3, 913-918. [CrossRef]

64. Beck, M.W.; Losada, I.J.; Menéndez, P.; Reguero, B.G.; Díaz-Simal, P.; Fernández, F. The global flood protection savings provided by coral reefs. Nat. Commun. 2018, 9, 1-9. [CrossRef] 
65. Del Valle, A.; Eriksson, M.; Ishizawa, O.A.; Miranda, J.J. Mangroves protect coastal economic activity from hurricanes. Proc. Natl. Acad. Sci. USA 2020, 117, 265-270. [CrossRef]

66. Sun, F.; Carson, R.T. Coastal wetlands reduce property damage during tropical cyclones. Proc. Natl. Acad. Sci. USA 2020 117, 5719-5725. [CrossRef] [PubMed]

67. Xiamen Evening News. The Total Area of Xiamen's Mangrove Forest Is about 2 Million Square Meters. Available online: http:/ /news.xmnn.cn/xmnn/2020/08/15/100767684.shtml (accessed on 7 March 2021).

68. Lin, P.; Zhang, Y.; Yang, Z. Protection and restoration of mangroves along the coast of Xiamen. J. Xiamen Univ. (Nat. Sci.) 2005, $44,1-6$

69. Morris, R.L.; Boxshall, A.; Swearer, S.E. Climate-resilient coasts require diverse defence solutions. Nat. Clim. Chang. 2020, 10, 485-487. [CrossRef] 